\title{
Editor's Message \\ Some ecological-hydrogeological lessons of the Chernobyl nuclear power plant accident
}

\author{
Genrich S. Vartanyan, Associate Editor
}

Prior to the accident at Russia's Chernobyl nuclear power plant (NPP), radioactive pollution of the geologic environment and natural waters, including groundwater, was not of high priority in Russia because international and national environmental monitoring programs after the nuclear and thermonuclear tests of the 1950-1960s did not indicate serious problems. It was generally accepted that the geological environment is a powerful barrier to anthropogenically produced radioactivity. Surface waters were also considered effectively self-purifying systems, while aquifers were considered to be naturally protected by overlying earth materials.

The high level of radioactive contamination observed today in the subsurface that is caused by natural and anthropogenic radioactive elements such as strontium-80, 90; cesium-134, 137; iodine-131; cobalt-60; plutonium239, 240 and other transuranic elements makes it especially important to assess the role of geology and hydrology in the accumulation, migration, and formation of radioactively polluted zones. Especially important is the role of groundwaters as well as pore solutions in the unsaturated zone, as these are the main transporting agents for any geochemical and/or radioactive compounds in the earth. The radioactive pollution of natural waters is becoming increasingly troublesome in Russia, especially in regions where radioactive wastes have been regularly discharged into open water reservoirs and in disposal sites for these wastes. Among the largest and most dramatic unsanctioned emissions of radionuclides over extensive territories was the explosion of the fourth power block at the Chernobyl NPP in April 1986, which resulted in fallout from the reactor's active zone of a very large quantity (about $1.9 \times 10^{18} \mathrm{~Bq}$ ) of radionuclides (without inert gases). According to an official estimate,

Published online: 20 September 2002

(C) Springer-Verlag 2002

G.S. Vartanyan ( $)$

All-Russian Research Institute for Hydrogeology

and Engineering Geology (VSEGINGEO),

142452 Zeleny-Village, Noginsk District,

Moscow Region, Russia

e-mail: gvartany@online.ru

it was equal to approximately $3.5 \%$ of the total radioactivity accumulated in this type of reactor. The radionuclide fallout had a wide distribution, covering all of eastern and western Europe. In the Russian Federation, the Chernobyl catastrophe affected 16 regions and 3 republics (Russia, Ukraine and Belarus), covering a total area of about $57,000 \mathrm{~km}^{2}$ with a radioactive contamination of over $1 \mathrm{Ci} / \mathrm{km}^{2}$. By the end of 1990 , the area polluted by cesium-137 in the former CIS counties (within the isoline of $1 \mathrm{Ci} / \mathrm{km}^{2}$ and higher) amounted to over $130,000 \mathrm{~km}^{2}$. The Chernobyl accident has had dramatic consequences and a tremendous impact on people's livelihood. About 1.8 million people in Russia, including 300,000 children, live on land contaminated by the radionuclide fallout from Chernobyl.

The basic and most medically and biologically hazardous radioactive nuclides emitted outside the active zone of the failed reactor are strontium-90 and cesium137 with half-lives of 30 years, as well as the plutonium isotopes with half-lives equal to a few tens of thousands of years. Thus, the accident has resulted in rather longlived radioactive contamination of the territory affecting millions of people. Apart from its direct impact on human health, the accident contaminated agricultural lands and water sources, local and regional surface water catchment areas, as well as the recharge areas of shallow unconfined and some deep aquifers used for the centralized water supply of the population.

The area most affected by the Chernobyl accident in Russia was the Bryansk region, where a territory of about $12,000 \mathrm{~km}^{2}$ was polluted by radioactive contaminants. The investigations carried out in this and adjacent regions to determine the contents of biologically hazardous radionuclides in the groundwater have shown a thorough penetration of anthropogenic radioactive isotopes to both the near-surface and deep aquifers.

The government of the Russian Federation has undertaken and continues to implement appropriate laws and 'federal purposeful programs' (FPP) to assist the people living in the territories affected by the Chernobyl accident. These programs provide for different actions, namely: radioecological monitoring; evacuation of people from contaminated territories to safe areas; environmental remediation of contaminated territories and support of the population; privileges and compensation for persons subjected to irradiation; and 
health protection and provision of basic needs, including safe water use.

In the framework of the government structure of the Russian Federation, the responsibility for monitoring the state of surface-water radiation in the territories affected by the Chernobyl NPP accident is entrusted to the Federal Service for Hydrometeorology and Environmental Monitoring (Roshydromet). The responsibility for monitoring the geological environment and groundwater is entrusted to the Ministry of Natural Resources, with the All-Russian Research Institute for Hydrogeology and Engineering Geology (VSEGINGEO) as the head organization. Initially, these works were carried out without any international assistance within the FPP and as projects in collaboration with regional and local departments. Later, after the economic reforms and financial crisis of the early 1990s in Russia, the research work was performed in cooperation with and financial support from international organizations, such as UNDP, UNESCO, IAEA, and others.

The investigations established for the period, August to October 1992, that the total concentration of radiocesium (including ionic and pseudocolloid forms) in shallow and deep groundwater exploited by the water intake of the Bryansk region, was equal to 7.4-259.0 and $7.4-136.9 \mathrm{mBq} / \mathrm{L}$, respectively. Furthermore, the results of multiyear (1987-1999) observations indicate that the concentrations of radiocesium and radiostrontium in shallow groundwater tended to increase with time. It has been found that the cesium-137 and strontium-90 concentrations in the groundwater increase with the density of the surface pollution, with a loss of infiltration recharge, and with the moisture level in the zone of aeration. These concentrations are inversely dependent upon the groundwater depth, the density of the rocks, and their clay content. All of these characteristics are clearly indicated by such parameters as the residence time and the retardation factor of water in a hydrogeological system.

Considerable variations are observed in the concentrations of radiocesium and radiostrontium even where the densities of the surface pollution are equal. This shows the essential influence of such factors as local heterogeneity of pollutants, specific protective properties of the rocks overlying the water-bearing systems, and the velocity with which radionuclides penetrate to aquifers.
Investigations of the VSEGINGEO Institute show that in order to obtain sufficient preliminary information on processes in aquifers, a highly effective technique is the combined use of natural isotopes, radio-indicators and penetration logging, which make it possible to evaluate the degree of natural groundwater protection against regional and local pollution. In particular, based on such investigations and using the concept of the residence and retardation factors, it has been established that, in general, the content of the Chernobyl cesium-137 in the shallow groundwater will never exceed the allowable level. There are exceptions for localized zones having a recharge rate of over $1,000 \mathrm{~mm} / \mathrm{year}$, a thin zone of aeration (no more than a few tens of centimeters), and a minimal retardation factor (pure sand). However, it is expected that, in the future, there will be a greater number of sites for penetration of radiostrontium, causing a higher content in the shallow groundwater, and it will be more widespread than at present.

Taking into consideration that it is impossible to study all of the polluted zones in detail, given the restricted time and financial resources, the following actions are planned:

1. Continuation of an areal examination of the geological environment and, initially, the zone of aeration, shallow and stratum groundwaters, in the regions affected by radionuclide pollution (i.e. radionuclide and isotope surveying, monitoring at reference points);

2. A study of mechanisms and characteristics of radionuclide migration in the geological environment, especially in water-bearing systems; and

3. Regular monitoring of the zone of aeration and groundwater in the areas where the penetration of radionuclides is detected and in the migration-hazard zones.

The experience of Chernobyl has tragically and unambiguously confirmed a long known truth: remediation of the consequences of a catastrophe is 2 to 3 orders of magnitude more expensive than the prevention of its causes. Prior detection of a risk and foresight concerning possible consequences are the appropriate means of dealing with hazards. 